\title{
IMPACT OF WASTEWATER DISCHARGE ON WATER QUALITY OF KAROON RIVER IN IRAN
}

\author{
G. BADALIANS GHOLIKANDI ${ }^{1}$, M. LASHGARI $^{2}$ \& E. DEHGHANIFARD ${ }^{3}$ \\ ${ }^{1}$ Power and Water University of Technology (PWUT), Water Research Institute (WRI), Tehran, Iran. \\ ${ }^{2}$ Tehran Water and Wastewater Company (TWWC), Tehran, Iran. \\ ${ }^{3}$ Environmental Health Engineering Department, School of Public Health, Iran University \\ of Medical Sciences/Water \& Wastewater Research Center, Water Research Institute (WRI), Tehran, Iran.
}

\begin{abstract}
Preservation of the Karoon and Dez Rivers, the fresh water resource, is of high importance in Khuzestan province with its rapid growth of population and agricultural and industrial activities. In this paper the water quality and quality conditions of four study areas are mapped, agricultural, industrial and urban pollutant sources identified, and their impact on biological, physical and chemical water quality of Karoon River examined. Twenty five quality monitoring stations were established to determine the pollution load to the Karoon and Dez Rivers. The analysis shows that wastewater discharge has different impacts on chemical and biological water quality in the four study areas, in both the short and long term.

Keywords: Dez River, Karoon River, wastewater discharge, water quality.
\end{abstract}

\section{INTRODUCTION}

River valleys generally constitute areas with the highest population density because of favorable living conditions such as fertile lands, water for irrigation, industrial or drinking purposes, and transportation. On the other hand, rivers play a major role in exporting and assimilating industrial and municipal wastewater, agricultural discharges, and runoff from agricultural fields, roadways and streets, which can lead to pollution of the rivers [1]. It is necessary for effective and efficient water management to have reliable information on water discharge and quality and the likely impact of pollution [2].

The Karoon River is a tributary of the Tigris-Euphrates River and has the largest drainage area in Iran. The Karoon River basin, with a basin area of $67,000 \mathrm{~km}^{2}$, is located in southern part of Iran between longitudes $48^{\circ} 15^{\prime}$ and $52^{\circ} 30^{\prime}$ east, latitude $30^{\circ} 17^{\prime}$ and $33^{\circ} 49^{\prime}$ north. The origin of the Karoon River is $75 \mathrm{~km}$ south of Esfahan city in the Zagros Mountain ranges and divided into two branches, Gargar and Shatit. North of Shooshtar city, in Ghir weir, the two branches and the Dez River join each other and form a great river called the Karoon. The upstream basin occupies the highly elevated Zagros mountain range which is subject to debris flows, landslides and floods. The Karoon is Iran's largest and only navigable river. It is 450 miles $(720 \mathrm{~km})$ long and serves the Khuzestan province. Many urban areas, industries and agricultural sites have been located near the Karoon River basin and unfortunately, most discharge their effluent into the river, without any treatment.

The water quality index (WQI) was developed to give the criteria for surface water classification based on the use of standard parameters for water characterization [3-16]. It is a mathematical instrument used to transform large quantities of water characterization data into a single number. Estimation of the WQI requires a normalization step where each parameter is transformed into a $0-100$ scale, where 100 represents the maximum quality. The next step is to apply a weighting factor in accordance with the importance of the parameter as an indicator of water quality $[7,8,13]$.

Brown et al. [17] developed a WQI for categorizing water resource uses based on their quality. This effort was supported by the National Sanitation Foundation (NSF). For this reason Brown's index is also referred as NSFWQI [17] (the National Sanitation Foundation Water Quality Index). 
In this study, the water quality of Karoon River and its branches was assessed and monitored in 2007-2008 by the NSFWQI method and zoning quality was done for the whole river. Also, the salinity parameter was assessed for some part of Karoon River.

\subsection{Sampling}

\section{MATERIALS AND METHODS}

The Karoon River has 25 monitoring stations for both quantity and quality of river's water, 20 of them located on the Karoon River and 5 stations on the Dez River (Fig. 1, Table 1). Sampling at these

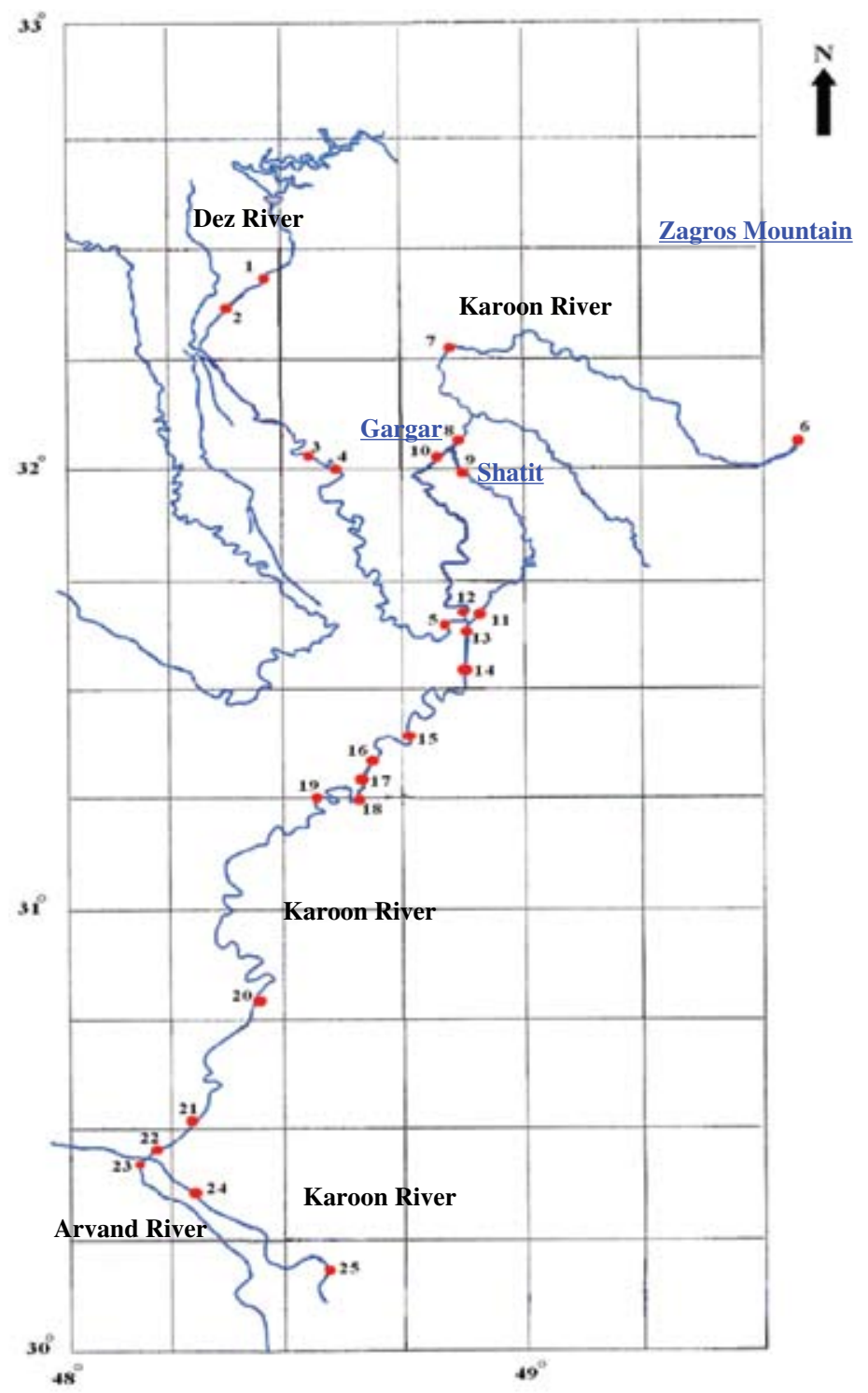

Figure 1: The Karoon River scheme, its branches and sampling station [18]. 
Table 1: Monitoring stations specification of Karoon River [18].

\begin{tabular}{|c|c|c|c|c|c|c|}
\hline \multirow[b]{2}{*}{ No. } & \multirow[b]{2}{*}{ Station name } & \multirow{2}{*}{$\begin{array}{l}\text { Distance } \\
\text { from source } \\
\quad(\mathrm{km})\end{array}$} & \multicolumn{3}{|c|}{ Geographical specification } & \multirow[b]{2}{*}{$\begin{array}{l}\text { Sampling } \\
\text { period }\end{array}$} \\
\hline & & & Longitude & Latitude & $\begin{array}{l}\text { Height } \\
(\mathrm{m})\end{array}$ & \\
\hline \multicolumn{7}{|c|}{ Dez River } \\
\hline 1 & Chamgalak & 18 & $48^{\circ} 28^{\prime} 46^{\prime \prime}$ & $32^{\circ} 26^{\prime} 47^{\prime \prime}$ & 330 & Seasonal \\
\hline 2 & Dezful Qand Industry & 44 & $48^{\circ} 20^{\prime} 00^{\prime \prime}$ & $32^{\circ} 14^{\prime} 15^{\prime \prime}$ & 350 & Seasonal \\
\hline 3 & Shirin Water & 83 & $48^{\circ} 31^{\prime} 30^{\prime \prime}$ & $32^{\circ} 02^{\prime} 45^{\prime \prime}$ & 334 & Seasonal \\
\hline 4 & Mostofi & 98 & $48^{\circ} 31^{\prime} 38^{\prime \prime}$ & $32^{\circ} 01^{\prime} 41^{\prime \prime}$ & 330 & Seasonal \\
\hline 5 & Dez-Ghir Weir & 152 & $48^{\circ} 52^{\prime} 15^{\prime \prime}$ & $31^{\circ} 38^{\prime} 45^{\prime \prime}$ & 330 & Monthly \\
\hline \multicolumn{7}{|c|}{ Karoon River } \\
\hline 6 & Abbaspour Dam & 0 & $49^{\circ} 36^{\prime} 40^{\prime \prime}$ & $32^{\circ} 01^{\prime} 05^{\prime \prime}$ & 368 & Seasonal \\
\hline 7 & Gatvand Dam & 153 & $48^{\circ} 49^{\prime} 19^{\prime \prime}$ & $32^{\circ} 14^{\prime} 43^{\prime \prime}$ & 375 & Seasonal \\
\hline 8 & Mizan Weir & 183 & $48^{\circ} 51^{\prime} 50^{\prime \prime}$ & $32^{\circ} 03^{\prime} 00^{\prime \prime}$ & 330 & Monthly \\
\hline 9 & Shatit-Shooshtar & 186 & $48^{\circ} 50^{\prime} 10^{\prime}$ & $32^{\circ} 02^{\prime} 50^{\prime \prime}$ & 330 & Seasonal \\
\hline 10 & Gargar-Shooshtar & 186 & $48^{\circ} 50^{\prime} 50^{\prime \prime}$ & $32^{\circ} 02^{\prime} 00^{\prime \prime}$ & 330 & Seasonal \\
\hline 11 & Shatit-Ghir Weir & 265 & $48^{\circ} 52^{\prime} 00^{\prime \prime}$ & $31^{\circ} 38^{\prime} 30^{\prime \prime}$ & 320 & Monthly \\
\hline 12 & Gargar-Ghir Weir & 262 & $48^{\circ} 53^{\prime} 15^{\prime \prime}$ & $31^{\circ} 39^{\prime} 00^{\prime \prime}$ & 320 & Monthly \\
\hline 13 & Karoon-Ghir Weir & 267 & $48^{\circ} 52^{\prime} 50^{\prime \prime}$ & $31^{\circ} 38^{\prime} 45^{\prime \prime}$ & 320 & Monthly \\
\hline 14 & Ramin & 284 & $48^{\circ} 52^{\prime} 30^{\prime \prime}$ & $31^{\circ} 29^{\prime} 30^{\prime \prime}$ & 328 & Seasonal \\
\hline 15 & Zargan & 318 & $48^{\circ} 45^{\prime} 30^{\prime \prime}$ & $31^{\circ} 24^{\prime} 00^{\prime \prime}$ & 320 & Monthly \\
\hline 16 & New Side & 334 & $48^{\circ} 42^{\prime} 00^{\prime \prime}$ & $31^{\circ} 19^{\prime} 30^{\prime \prime}$ & 320 & Seasonal \\
\hline 17 & Ahvaz 5th Bridge & 340 & $48^{\circ} 39^{\prime} 30^{\prime \prime}$ & $31^{\circ} 18^{\prime} 00^{\prime \prime}$ & 320 & Seasonal \\
\hline 18 & Chanibie & 344 & $48^{\circ} 39^{\prime} 30^{\prime \prime}$ & $31^{\circ} 16^{\prime} 10^{\prime \prime}$ & 320 & Seasonal \\
\hline 19 & Um Al Tamir & 368 & $48^{\circ} 33^{\prime} 35^{\prime \prime}$ & $31^{\circ} 14^{\prime} 45^{\prime \prime}$ & 320 & Monthly \\
\hline 20 & Darkhovein & 476 & $48^{\circ} 25^{\prime} 00^{\prime \prime}$ & $30^{\circ} 43^{\prime} 45^{\prime \prime}$ & 305 & Seasonal \\
\hline 21 & Nahrmard & 512 & $48^{\circ} 18^{\prime} 00^{\prime \prime}$ & $30^{\circ} 30^{\prime} 00^{\prime \prime}$ & 304 & Seasonal \\
\hline 22 & $\begin{array}{l}\text { Khorramshahr Soap } \\
\text { Industry }\end{array}$ & 524 & $48^{\circ} 12^{\prime} 50^{\prime \prime}$ & $30^{\circ} 25^{\prime} 30^{\prime \prime}$ & 303 & Monthly \\
\hline 23 & Haffar & 528 & $48^{\circ} 12^{\prime} 45^{\prime \prime}$ & $30^{\circ} 26^{\prime} 05^{\prime \prime}$ & 303 & Monthly \\
\hline 24 & Bahmanshir & 541 & $48^{\circ} 19^{\prime} 30^{\prime \prime}$ & $30^{\circ} 19^{\prime} 20^{\prime \prime}$ & 303 & Seasonal \\
\hline 25 & Choebade & 576 & $48^{\circ} 35^{\prime} 00^{\prime \prime}$ & $30^{\circ} 11^{\prime} 30^{\prime \prime}$ & 302 & Monthly \\
\hline
\end{tabular}

stations is either seasonal or monthly. Figure 2 shows main pollutant sources around the Karoon and Dez Rivers. Most of the industries are food-related industries.

The water quality and quantity data used in this study was obtained from the Khuzestan water and wastewater company [18] and is for the period September 2007 to March 2008. The water quality parameters that are used in this study are dissolved oxygen (DO), $\mathrm{pH}$, Biochemical oxygen demand $\left(\mathrm{BOD}_{5}\right)$, Temperature $\left(\mathrm{T}^{\circ}\right)$, Turbidity, Total solids $(\mathrm{TS})$, Nitrate $\left(\mathrm{NO}_{3}\right)$, Phosphate $\left(\mathrm{PO}_{4}\right)$ and Fecal coliforms (FC). Electrical conductivity (EC) and Chloride Ion $\left(\mathrm{Cl}^{-}\right)$were also measured at 11 sampling stations near Ahvaz and Abadan cities as a means of determining the salinity of Dez and Karoon Rivers during the period September 2007 to March 2008. Analyzing of all these parameters was in accordance with the Standard methods for the examination of water and wastewater [19]. It is realized that the sampling period is short ( 6 months) but this study of the trends and sources of pollution did not require a more detailed and longer period of records. The period is the wet-season period for the area. 


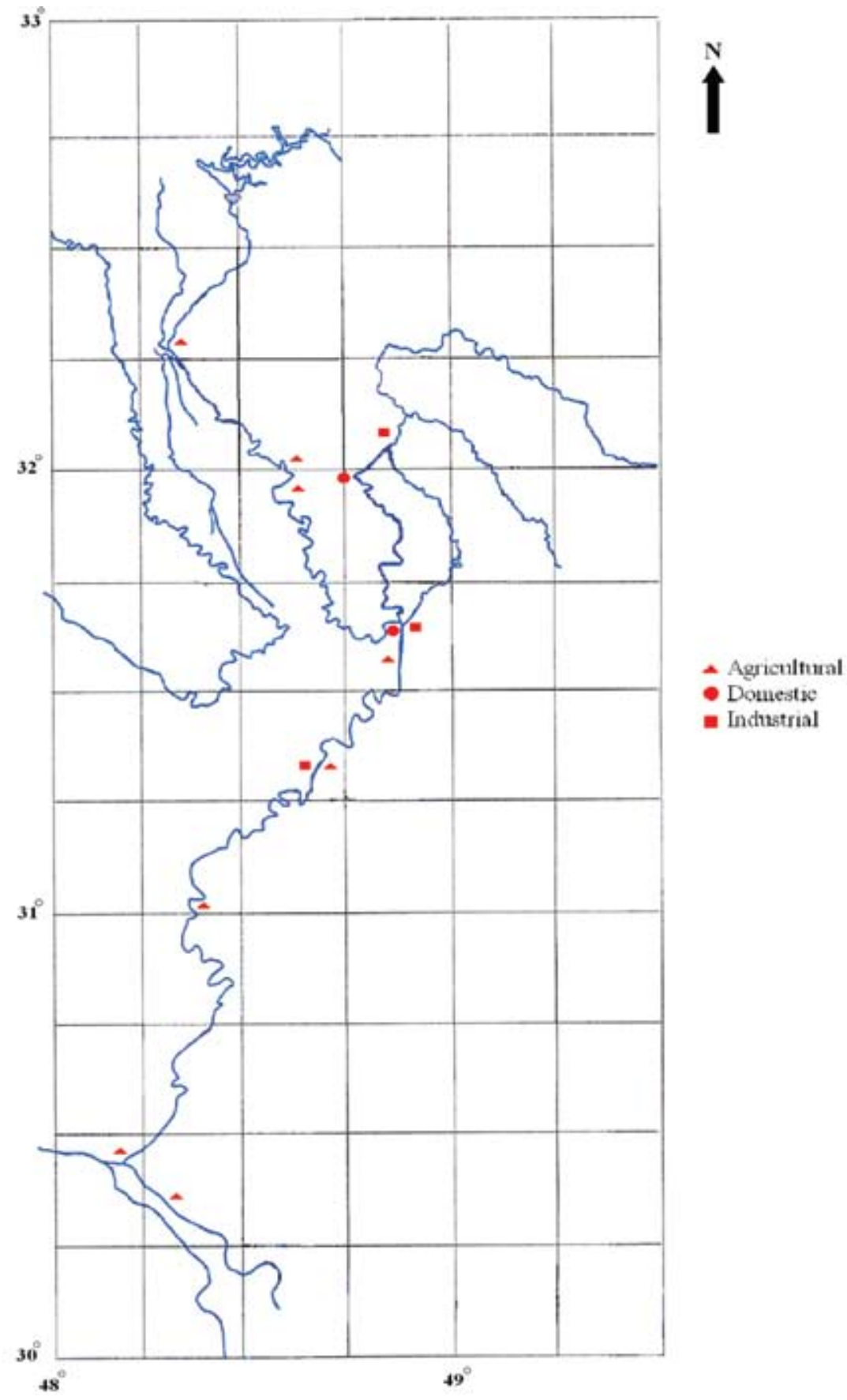

Figure 2: Main pollutant sources around Karoon and Dez Rivers [20, 23]. 


\subsection{Data analysis}

The weight factor for NSFWQI was developed using a modified version of the questionnaire of Brown et al. [17].

A panel of 18 persons with expertise in water quality management was formed for this study. They have been working on water resources quality management in four significant universities of Iran (Tehran, Sharif, Science and Technology, Amir Kabir). The panelists were asked to rank the NSFWQI parameters according to their significance as contributors to overall quality. The rating was done on a scale of 1 (highest) to 5 (lowest). The responses of the panel were brought to the knowledge of every member of the panel and the members were allowed to review their individual judgment in the light of the full panel's response. The weighting factors were calculated according to the following steps:

1. The responses of each rank were determined on a scale of 1 to 5 ;

2. The weighting average of each parameter portion was calculated;

3. The temporary weighting factor was calculated by dividing parameter portion to smallest portion and

4. Dividing the temporary weight factor of each parameter to the sum of temporary weight factors for calculating final weight factor of each parameter.

The index developed by the method of Brown et al. [17] is given by

$$
\mathrm{NSFWQI}=\sum_{i=1}^{n} W_{i} I_{i}
$$

where $I_{i}=$ the quality of the $i$ th parameter (a number between 0 and 100 read from the appropriate sub-index graph) and $W_{i}=$ the weight factor of the $i$ th parameter.

However, in cases of weak sub-indices (near to zero), a modified equation was used [21]:

$$
\mathrm{NSFWQI}=\prod_{i=1}^{n} I_{i}{ }^{W_{i}}
$$

In this study, eqn (2) was used to assess the water quality indices based on the NSFWQI method.

The salinity parameter was determined by the $\mathrm{EC}$ and $\mathrm{Cl}^{-}$monthly measurement of Karoon River near to Ahvaz and Abadan cities.

\section{RESULTS}

Table 2 shows the results of temporary and final weight factors of NSFWQI parameters that were concluded from the questionnaire of this study. As can be seen, these factors differ from the original NSFWQI factors. The maximum difference is about $30 \%$ for $\mathrm{BOD}_{5}$ and temperature. Turbidity was omitted due to the low turbidity of water samples during the period of the study and an inability to fit this parameter to the NSFWQI chart. So, the temporary and final weight factors of NSFWQI parameters were recalculated without turbidity (Table 3). In Table 4, the sub-index quantities of quality factors of NSFWQI for each sampling station of Karoon and Dez Rivers have been demonstrated. As shown, the turbidity parameter was omitted due to its low value. Table 5 shows the final index of NSFWQI and its quality meaning for both original and recalculated weight factors. The final index shows the water quality at each. Table 6 shows the $\mathrm{EC}$ and $\mathrm{Cl}^{-}$that were measured in 10 sampling stations near Ahvaz city. As can be seen, some data were omitted because they were not in the Khuzestan Water and Wastewater Company database. 
Table 2: Temporary and final weight factors of NSFWQI parameters.

\begin{tabular}{|c|c|c|c|c|c|c|c|c|c|}
\hline \multirow[b]{2}{*}{ Quality parameter } & \multicolumn{5}{|c|}{ Power of polluting } & \multirow[b]{2}{*}{ Average } & \multirow{2}{*}{$\begin{array}{c}\text { Temporary } \\
\text { weight factor }\end{array}$} & \multirow{2}{*}{$\begin{array}{l}\text { Final } \\
\text { weight } \\
\text { factor }\end{array}$} & \multirow{2}{*}{$\begin{array}{l}\text { Original } \\
\text { final weight } \\
\text { factor }\end{array}$} \\
\hline & 1 & 2 & 3 & 4 & 5 & & & & \\
\hline DO & 8 & 5 & 4 & 1 & - & 1.888 & 0.82 & 0.13 & 0.17 \\
\hline $\mathrm{BOD}_{5}$ & 10 & 6 & 2 & - & - & 1.556 & 1.00 & 0.15 & 0.11 \\
\hline $\mathrm{pH}$ & 3 & 8 & 5 & 2 & - & 2.333 & 0.67 & 1.10 & 0.11 \\
\hline Nitrate & 7 & 4 & 6 & - & 1 & 2.111 & 0.74 & 0.11 & 0.10 \\
\hline Phosphate & 3 & 3 & 9 & 2 & 1 & 2.722 & 0.57 & 0.09 & 0.10 \\
\hline TS & 4 & 8 & 2 & 4 & - & 2.333 & 0.67 & 0.10 & 0.07 \\
\hline $\mathrm{T}^{\circ}$ & 1 & 1 & 8 & 5 & 3 & 3.44 & 0.45 & 0.07 & 0.10 \\
\hline Turbidity & 4 & 6 & 5 & 3 & - & 2.389 & 0.65 & 0.10 & 0.08 \\
\hline Fecal coliforms & 11 & 3 & 3 & 1 & - & 1.667 & 0.93 & 0.14 & 0.16 \\
\hline & & & & & & Sum & 6.5 & & \\
\hline
\end{tabular}

Table 3: Modified temporary and final weight factors of NSFWQI parameters without turbidity parameter.

\begin{tabular}{lcccc}
\hline Quality parameter & Average & $\begin{array}{c}\text { Temporary } \\
\text { weight factor }\end{array}$ & $\begin{array}{c}\text { Final } \\
\text { weight factor }\end{array}$ & $\begin{array}{c}\text { Original final } \\
\text { weight factor }\end{array}$ \\
\hline DO & 1.4 & 1.00 & 0.19 & 0.17 \\
BOD $_{5}$ & 2.3 & 0.61 & 0.11 & 0.11 \\
pH & 2.1 & 0.67 & 0.12 & 0.11 \\
Nitrate & 2.4 & 0.58 & 0.11 & 0.10 \\
Phosphate & 2.4 & 0.58 & 0.11 & 0.10 \\
TS & 3.2 & 0.44 & 0.08 & 0.07 \\
$T^{\circ}$ & 2.4 & 0.58 & 0.11 & 0.10 \\
Fecal coliforms & 1.5 & 0.93 & 0.17 & 0.16 \\
& Sum & 5.39 & 1 & \\
\hline
\end{tabular}

Table 4: The sub-index quantities of quality factors of NSFWQI for each sampling station of Karoon and Dez Rivers.

\begin{tabular}{|c|c|c|c|c|c|c|c|c|c|}
\hline \multirow[b]{2}{*}{ No. } & \multirow[b]{2}{*}{ Station } & \multicolumn{8}{|c|}{ Parameter } \\
\hline & & $\mathrm{pH}$ & DO & $\mathrm{T}^{\circ}$ & $\mathrm{TS}$ & $\mathrm{BOD}_{5}$ & Nitrate & Phosphate & $\begin{array}{c}\text { Fecal } \\
\text { coliforms }\end{array}$ \\
\hline \multicolumn{10}{|c|}{ Dez River } \\
\hline 1 & Chamgalak & 91 & 76 & 90 & 58 & 80 & 92 & 100 & 22 \\
\hline 2 & Dezful Qand Industry & 84 & 88 & 90 & 20 & 76 & 82 & 100 & 22 \\
\hline 3 & Shirin Water & 89 & 71 & 90 & 20 & 58 & 75 & 100 & 22 \\
\hline 4 & Mostofi & 90 & 51 & 90 & 20 & 64 & 69 & 99 & 22 \\
\hline 5 & Dez-Ghir Weir & 89 & 65 & 90 & 20 & 76 & 84 & 100 & 22 \\
\hline \multicolumn{10}{|c|}{ Karoon River } \\
\hline 6 & Abbaspour Dam & 91 & 73 & 90 & 60 & 80 & 89 & 99 & 22 \\
\hline 7 & Gatvand Dam & 88 & 80 & 90 & 20 & 92 & 88 & 100 & 22 \\
\hline
\end{tabular}


Table 4: Continued

\begin{tabular}{|c|c|c|c|c|c|c|c|c|c|}
\hline \multirow[b]{2}{*}{ No. } & \multirow[b]{2}{*}{ Station } & \multicolumn{8}{|c|}{ Parameter } \\
\hline & & $\mathrm{pH}$ & DO & $\mathrm{T}^{\circ}$ & $\mathrm{TS}$ & $\mathrm{BOD}_{5}$ & Nitrate & Phosphate & $\begin{array}{c}\text { Fecal } \\
\text { coliforms }\end{array}$ \\
\hline 9 & Shatit-Shooshtar & 82 & 80 & 90 & 20 & 74 & 92 & 99 & 9 \\
\hline 10 & Gargar-Shooshtar & 81 & 78 & 90 & 20 & 63 & 85 & 100 & 9 \\
\hline 11 & Shatit-Ghir Weir & 87 & 80 & 90 & 20 & 86 & 90 & 100 & 9 \\
\hline 12 & Gargar-Ghir Weir & 85 & 82 & 90 & 20 & 76 & 81 & 99 & 9 \\
\hline 13 & Karoon-Ghir Weir & 89 & 75 & 90 & 20 & 82 & 83 & 100 & 9 \\
\hline 14 & Ramin & 89 & 77 & 90 & 20 & 86 & 82 & 94 & 9 \\
\hline 15 & Zargan & 88 & 68 & 90 & 20 & 86 & 71 & 100 & 8 \\
\hline 16 & New Side & 89 & 79 & 90 & 20 & 74 & 82 & 99 & 8 \\
\hline 17 & Ahvaz 5th Bridge & 90 & 79 & 90 & 20 & 70 & 92 & 98 & 8 \\
\hline 18 & Chanibie & 88 & 74 & 90 & 20 & 67 & 82 & 98 & 8 \\
\hline 19 & Um Al Tamir & 89 & 69 & 90 & 20 & 67 & 79 & 100 & 9 \\
\hline 20 & Darkhovein & 87 & 78 & 90 & 20 & 82 & 83 & 100 & 9 \\
\hline 21 & Nahrmard & 84 & 86 & 90 & 20 & 80 & 79 & 99 & 9 \\
\hline 22 & $\begin{array}{l}\text { Khorramshahr Soap } \\
\text { Industry }\end{array}$ & 88 & 57 & 90 & 20 & 69 & 70 & 100 & 9 \\
\hline 23 & Haffar & 86 & 76 & 90 & 20 & 67 & 81 & 99 & 22 \\
\hline 24 & Bahmanshir & 71 & 76 & 90 & 20 & 70 & 89 & 99 & 22 \\
\hline 25 & Choebade & 81 & 76 & 90 & 20 & 68 & 80 & 99 & 22 \\
\hline
\end{tabular}

Table 5: The final index of NSFWQI and its quality meaning for both original and recalculated weight factors.

\begin{tabular}{clllcl}
\hline & & \multicolumn{4}{c}{ Quality index } \\
\cline { 3 - 6 } No. & \multicolumn{1}{c}{ Station } & Original index & $\begin{array}{c}\text { Original index } \\
\text { meaning }\end{array}$ & $\begin{array}{c}\text { Recalculated } \\
\text { index }\end{array}$ & $\begin{array}{c}\text { Recalculated index } \\
\text { meaning }\end{array}$ \\
\hline $\begin{array}{c}\text { Dez } \\
\text { River }\end{array}$ & Chamgalak & 66.38 & Medium & 66.48 & Medium \\
2 & Dezful Qand Industry & 60.96 & Medium & 58.43 & Medium \\
3 & Shirin Water & 56.64 & Medium & 53.88 & Medium \\
4 & Mostofi & 53.29 & Medium & 51.75 & Medium \\
5 & Dez-Ghir Weir & 58.10 & Medium & 56.54 & Medium \\
Karoon River & & & & \\
6 & Abbaspour Dam & 65.74 & Medium & 66.01 & Medium \\
7 & Gatvand Dam & 61.96 & Medium & 60.42 & Medium \\
8 & Mizan Weir & 61.08 & Medium & 58.68 & Medium \\
9 & Shatit-Shooshtar & 51.72 & Medium & 50.32 & Bad-Medium \\
10 & Gargar-Shooshtar & 50.11 & Bad-Medium & 48.27 & Bad \\
11 & Shatit-Ghir Weir & 52.89 & Medium & 51.86 & Medium \\
12 & Gargar-Ghir Weir & 51.61 & Medium & 50.08 & Bad-Medium \\
13 & Karoon-Ghir Weir & 51.65 & Medium & 50.57 & Bad-Medium \\
14 & Ramin & 51.76 & Medium & 50.77 & Bad-Medium \\
\hline
\end{tabular}


Table 5: Continued

\begin{tabular}{llclcc}
\hline & & \multicolumn{4}{c}{ Quality index } \\
\cline { 3 - 6 } No. & \multicolumn{1}{c}{ Station } & Original index & $\begin{array}{c}\text { Original index } \\
\text { meaning }\end{array}$ & $\begin{array}{c}\text { Recalculated } \\
\text { index }\end{array}$ & $\begin{array}{c}\text { Recalculated index } \\
\text { meaning }\end{array}$ \\
\hline 15 & Zargan & 49.04 & Bad & 48.30 & Bad \\
16 & New Side & 51.45 & Medium & 49.00 & Bad \\
17 & Ahvaz 5th Bridge & 50.77 & Bad-Medium & 49.28 & Bad \\
18 & Chanibie & 49.15 & Bad & 47.63 & Bad \\
19 & Um Al Tamir & 49.45 & Bad & 47.49 & Bad \\
20 & Darkhovein & 51.75 & Medium & 50.51 & Bad-Medium \\
21 & Nahrmard & 51.16 & Medium & 50.63 & Bad-Medium \\
22 & Khorramshahr Soap & 47.15 & Bad & 46.17 & Bad \\
& Industry & & & & \\
23 & Haffar & 58.58 & Medium & 56.17 & Medium \\
24 & Bahmanshir & 59.05 & Medium & 56.85 & Medium \\
25 & Choebade & 58.08 & Medium & 55.72 & Medium \\
\hline
\end{tabular}

Table 6: $\mathrm{EC}$ (in $\mu \mathrm{Mohs} / \mathrm{cm}$ ) and $\mathrm{Cl}^{-}$(in $\mathrm{mg} / \mathrm{L}$ ) quantities in 11 sampling stations.

\begin{tabular}{|c|c|c|c|c|c|c|c|c|c|c|c|c|c|c|}
\hline \multirow[b]{3}{*}{ Stations } & \multicolumn{14}{|c|}{ Month } \\
\hline & \multicolumn{2}{|c|}{ September } & \multicolumn{2}{|c|}{ October } & \multicolumn{2}{|c|}{ November } & \multicolumn{2}{|c|}{ December } & \multicolumn{2}{|c|}{ January } & \multicolumn{2}{|c|}{ February } & \multicolumn{2}{|c|}{ March } \\
\hline & $\mathrm{EC}$ & $\mathrm{Cl}^{-}$ & $\mathrm{EC}$ & $\mathrm{Cl}^{-}$ & $\mathrm{EC}$ & $\mathrm{Cl}^{-}$ & $\mathrm{EC}$ & $\mathrm{Cl}^{-}$ & $\mathrm{EC}$ & $\mathrm{Cl}^{-}$ & $\mathrm{EC}$ & $\mathrm{Cl}^{-}$ & $\mathrm{EC}$ & $\mathrm{Cl}^{-}$ \\
\hline 1 & 311 & 22.68 & 359 & - & 395 & 38.4 & 525 & - & 541 & - & 523 & 60 & 487 & - \\
\hline 2 & - & 78.84 & 1520 & - & 1032 & 132.8 & 970 & - & 1500 & - & 1050 & 110 & 1270 & - \\
\hline 3 & 1000 & 111.2 & 799 & - & 1080 & 147.6 & 1220 & - & 1440 & - & 1220 & 237 & 1590 & - \\
\hline 4 & - & 118.26 & 1230 & - & 1350 & 259.8 & 1650 & - & 2240 & - & 2460 & 379 & 1550 & - \\
\hline 5 & - & 216 & 1920 & - & 2040 & 232.2 & 2620 & - & 3120 & - & 1890 & 303 & 1900 & - \\
\hline 8 & - & 115.56 & 1390 & - & 1240 & 231.2 & 1180 & - & 1780 & - & 2120 & 277 & 1530 & - \\
\hline 13 & 1590 & 142.56 & 1420 & - & 1340 & 246 & 1420 & - & 2100 & - & 1750 & 265 & 1670 & - \\
\hline 14 & 1410 & 120.96 & 1390 & - & 1100 & 232.2 & 1630 & - & 2120 & - & 1720 & 245 & 1830 & - \\
\hline 17 & 1480 & 154.44 & 1630 & - & 1300 & 198.7 & 1300 & - & 2600 & - & 2240 & 390 & 1410 & - \\
\hline 18 & 1510 & 154.44 & 1610 & - & 1300 & 227.3 & 1360 & - & 2500 & - & 2240 & 395 & 1500 & - \\
\hline 19 & 4610 & 706 & 4580 & - & 1750 & 314.9 & 2150 & - & 2600 & - & 2200 & 438 & 2720 & - \\
\hline
\end{tabular}

\section{DISCUSSION}

Figures 3 and 4 show the trends in the physical, chemical and biological sub-indices along the length of the Dez and Karoon Rivers, respectively. Only temperature has a significant change between stations 1 and 2 along the Dez River from 60 to 20, pH declined from 90 to 81 in this River and TS is stable(Fig. 3a). Agricultural discharges along the Dez River account for the change (Fig. 2). Quality deterioration problem can be observed in chemical and biological sub-indices along the Dez River (Fig. 3b and c). Only the phosphate sub-index is stable. The DO increased from 73 at the first station to 78 at the fifth station. Figure 4a shows that the $\mathrm{pH}$ sub-index has an almost stable trend and only 


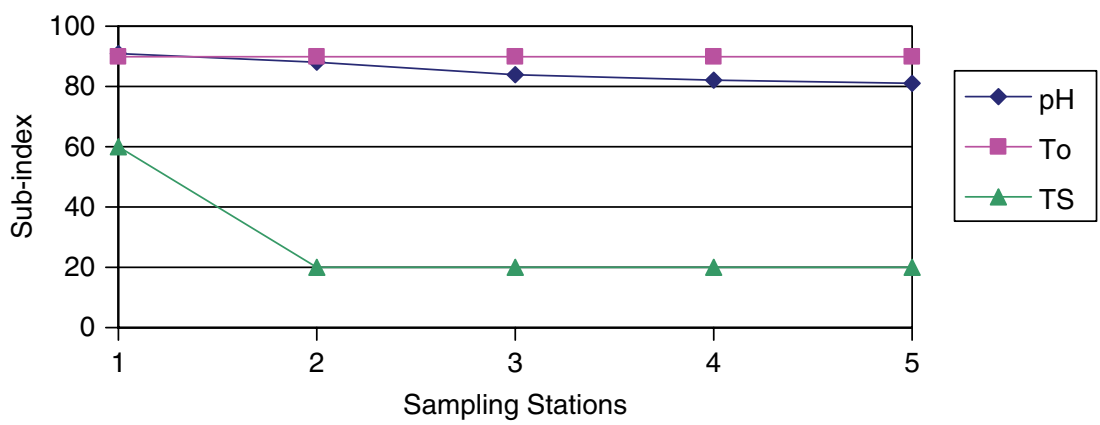

(a)

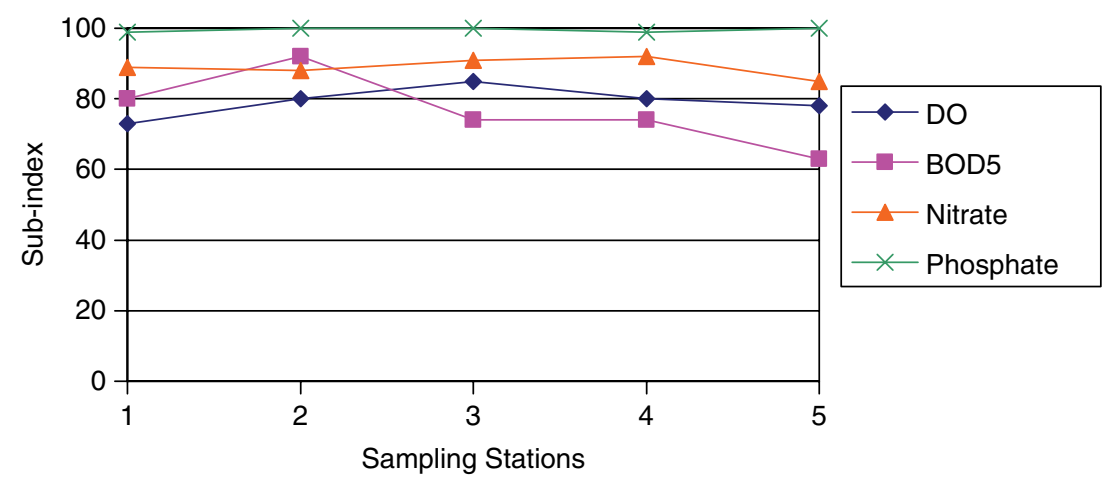

(b)

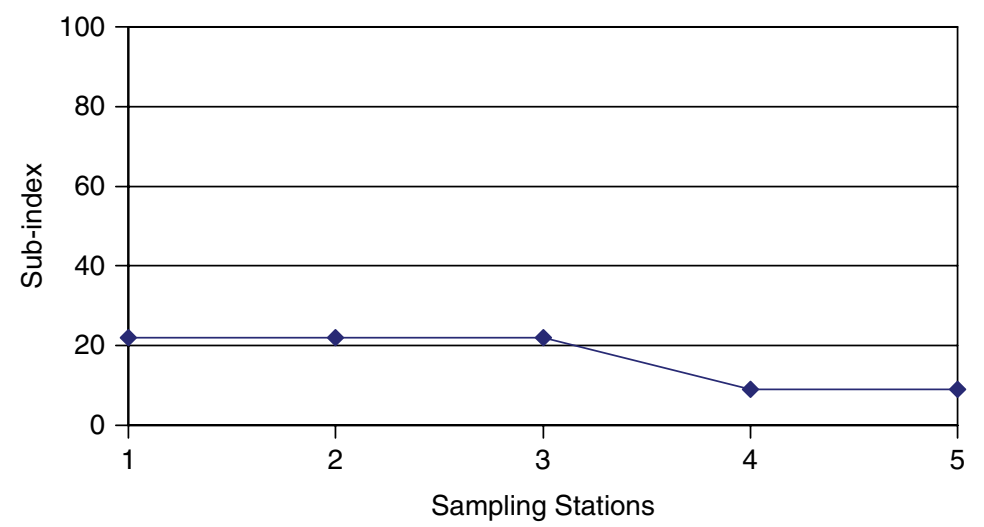

(c)

Figure 3: Changes trend of sub-indices in the length of Dez River: (a) physical, (b) chemical, (c) biological.

decreased in station 19 to 71 . although it increased to 91 at station 21. Other physical sub-indices are stable along the length of the Karoon River. The average of physical sub-indices of the Karoon River is $86.24 \pm 4.70$ for $\mathrm{pH}, 90 \pm 0.00$ for temperature and $20 \pm 0.00$ for TS. Chemical sub-indices trends (Fig. 4b) show that only the phosphate sub-index had an almost stable trend with average of 


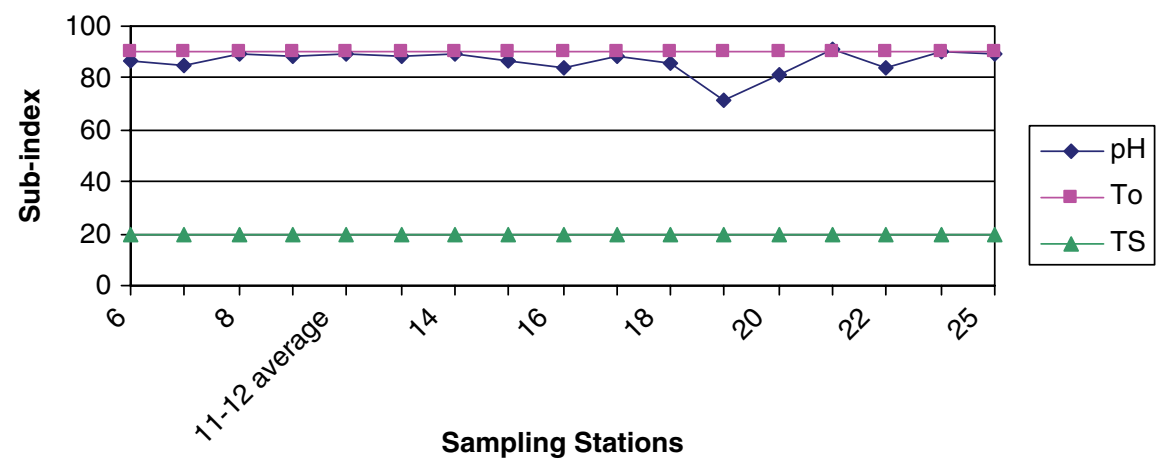

(a)

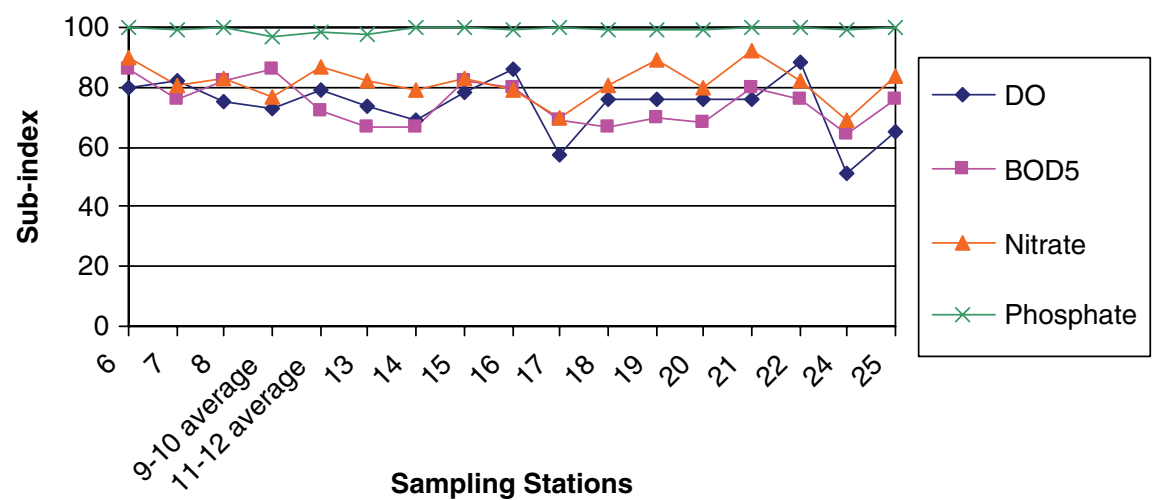

(b)

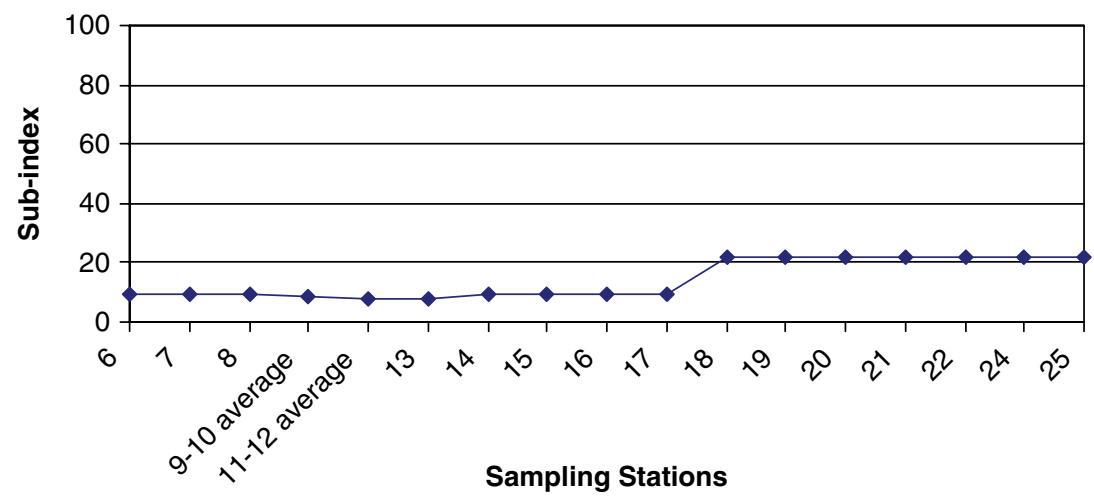

(c)

Figure 4: Changes trend of sub-indices in the length of Karoon River: (a) physical, (b) chemical, (c) biological. 
$99.26 \pm 0.87$ and DO has the most unstable trend of $74.15 \pm 9.43$ along the length of the Karoon River. The Nitrate and $\mathrm{BOD}_{5}$ sub-indices also have stable trends with $81.62 \pm 6.17$ and $74.59 \pm 5.17$, respectively. The $\mathrm{BOD}_{5}$ and $\mathrm{DO}$ sub-indices do not have similar trends. Overall, it could be concluded that self-purification in the Karoon River is not coping with wastewater discharge. Figures 5 and 6 demonstrate salinity changes in the Dez and Karoon Rivers, respectively. The water quality deterioration in both Dez and Karoon Rivers is evident in the salinity trend. The $\mathrm{Cl}^{-}$concentration is more than the standard for domestic and industrial uses, but is suitable for agriculture and irrigation [22].

In general, wastewater discharges from several points (industrial, agricultural, domestic, etc.) in the Karoon River caused water quality decline along the length of the Karoon River. However, the self-purification capacity of the Karoon River resulted in an improvement in the quality of Karoon River towards the bottom of the catchment. In Fig. 7, quality zoning of Dez and Karoon Rivers based on recalculated NSFWQI is demonstrated. The water quality of the Dez River and Karoon branch were in medium condition while the water quality between the stations 10 and 12 was classified as bad to medium and this condition continues to station 14 . The water quality of the Karoon River between the stations 14-19 declines. The water quality

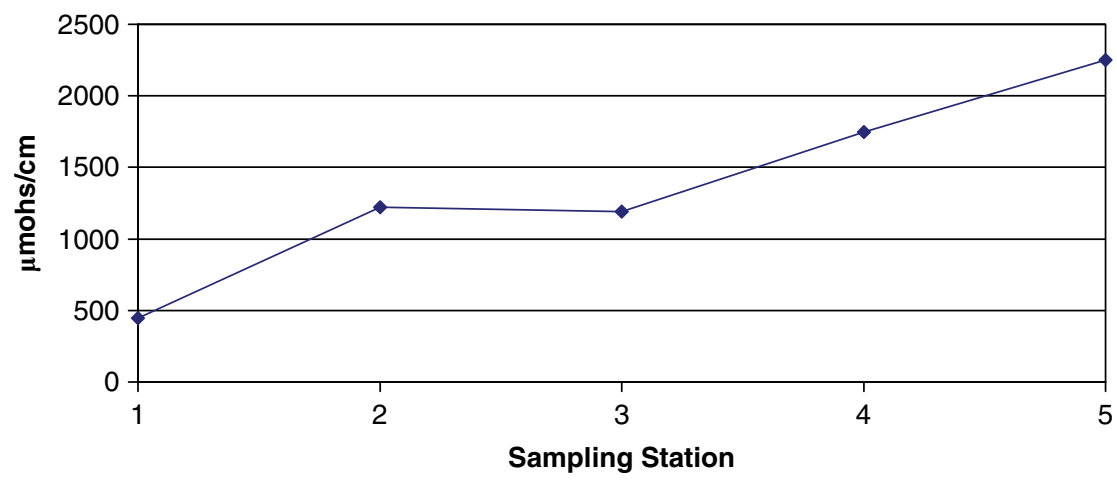

(a)

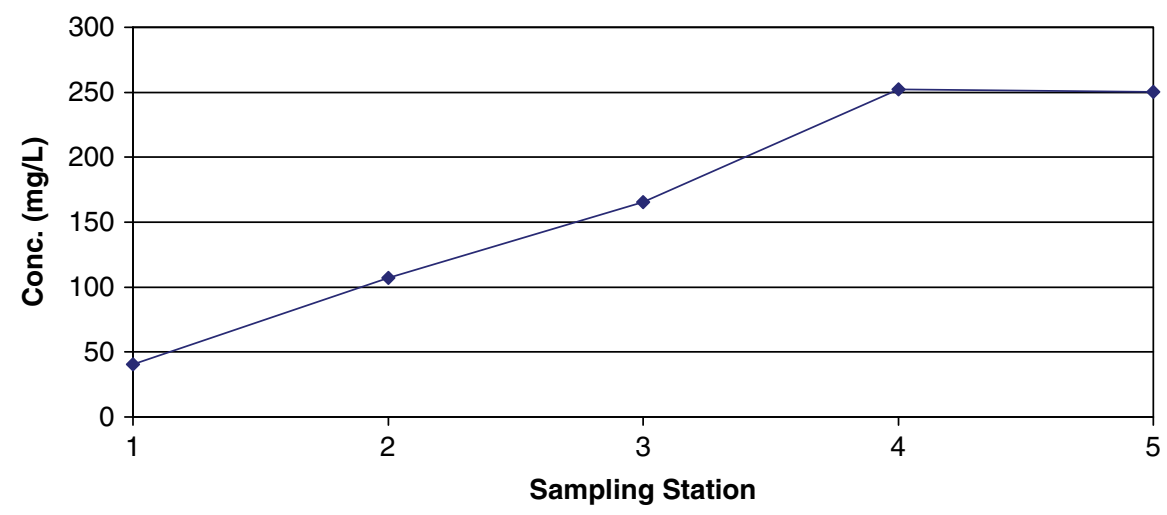

(b)

Figure 5: Salinity changes trend of Dez River: (a) EC, (b) $\mathrm{Cl}^{-}$. 


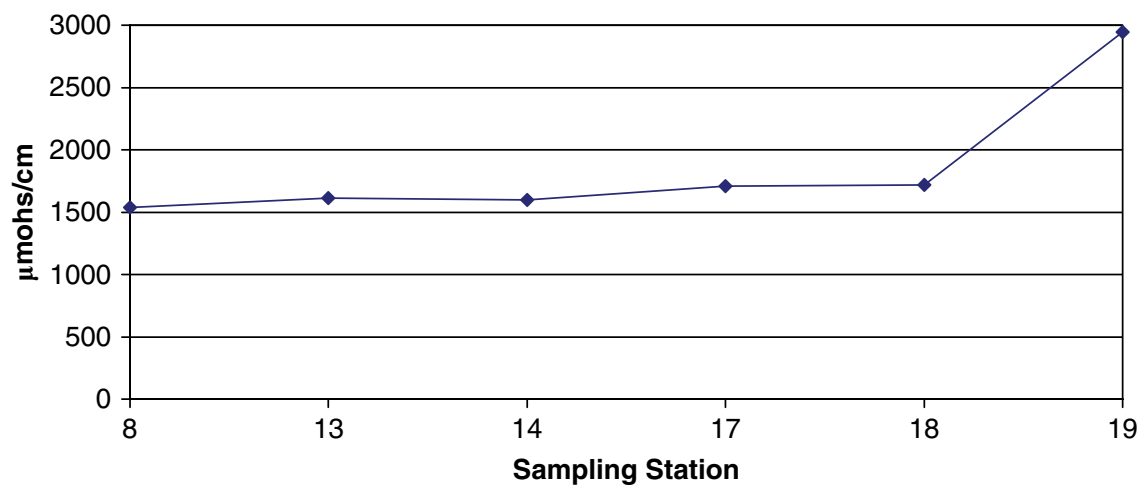

(a)

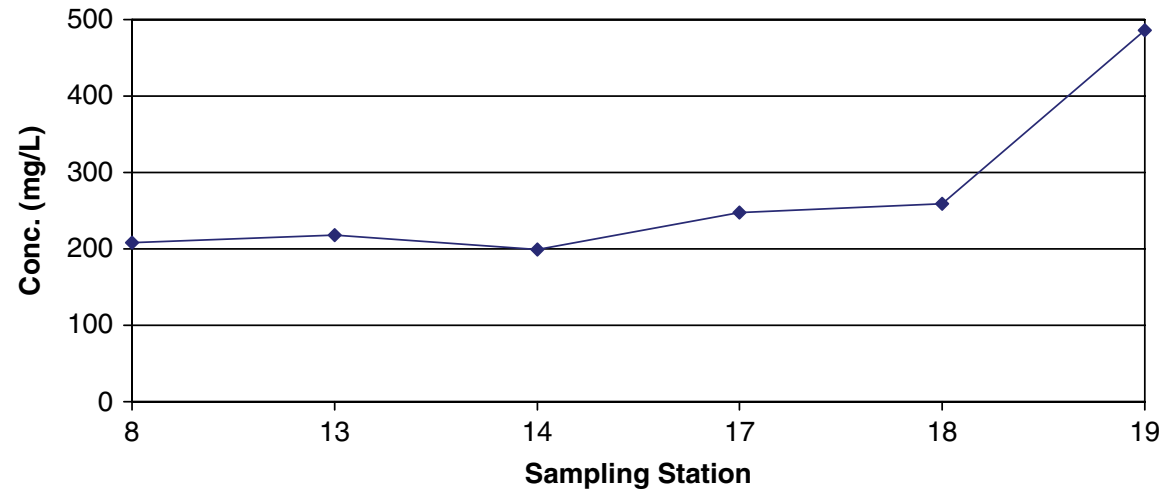

(b)

Figure 6: Salinity changes trend of Karoon River: (a) EC, (b) $\mathrm{Cl}^{-}$.

of the Karoon River improves in the lower section of the river, probably because of inflow from the Arvand River.

In general, the Dez River is suitable for recreational uses, but needs conventional treatment of industrial and domestic uses. However, the Karoon River is not suitable for recreational uses and needs advanced treatment of industrial and domestic uses.

\section{CONCLUSION}

The National Sanitation Foundation Water Quality Index, which gives a single value to the water quality of a river enabled an evaluation of water quality trends and likely causes of deteriotation in water quality along rivers in the Karoon River catchment. The Karoon River is the longest and one of the most important rivers in Iran and is an important source of water for agricultural, industrial, domestic and recreational uses. Thus, having water quality indices and zoning plan for this river aid the experts to better manage how to use the water for suitable uses based on its quality and also discharge wastewaters to this river. Unfortunately, this study shows that the water quality of the Dez and Karoon Rivers is poor, probably due to wastewater discharges. An integrated program to manage water quality along the Dez and Karoon Rivers is required if the resource is not to be further degraded. 


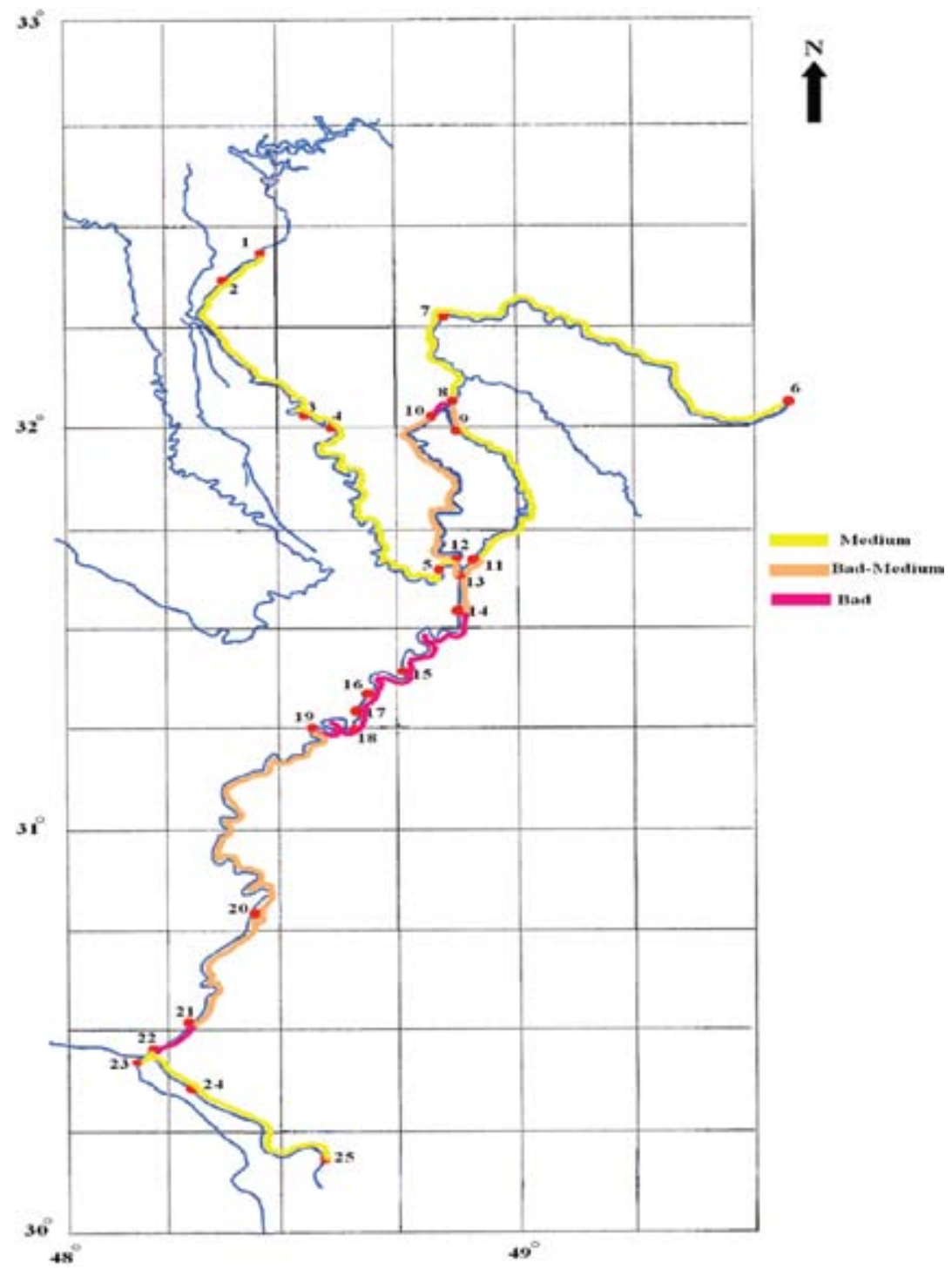

Figure 7: Quality zoning of Dez and Karoon Rivers based on recalculated NSFWQI.

\section{ACKNOWLEDGEMENTS}

The authors acknowledged the Iranian Ministry of Energy and Water Research Institute for their fund supporting of this study.

\section{REFERENCES}

[1] Stroomberg, G.J., et al., Quality Assurance and Quality Control of Surface Water Sampling, in Quality Assurance in Environmental Monitoring, Verlaggesellschaft $\mathrm{mbH}$ : Weinheim, pp. 52-90, 1995.

[2] Vega, M., et al., Assessment of seasonal and polluting effects on the quality of river water by exploratory data analysis. Water Research, 32(12), pp. 3581-3592, 1998. doi:10.1016/S00431354(98)00138-9 
[3] Couillard, D. \& Lefebvre, Y., Analysis of water quality indexes. Journal of Environment Management, 21, pp. 161-179, 1985.

[4] House, M.A. \& Newsome, D.H., Water quality indices for the management of surface water quality. Water Science and Technology, 21, pp. 1137-1148, 1989.

[5] Smith, D.G., A new form of water quality index for rivers and streams. Water Science and Technology, 21, pp. 123-127, 1989.

[6] Melloul, A.J. \& Collin, M., A proposed index for aquifer water quality assessment: the case of Israel's Sharon region. Journal of Environment Management, 54, pp. 131-142, 1998. doi:10.1006/jema.1998.0219

[7] Nives, S.G., Water quality evaluation by index in Dalamatia. Water Research, 33, pp. 3423-3440, 1999. doi:10.1016/S0043-1354(99)00063-9

[8] Pesce, S.F. \& Wunderlin, D.A., Use of water quality indices to verify the impact of Cordoba city (Argentina) on Suquia River. Water Research, 34, pp. 2915-2926, 2000. doi:10.1016/ S0043-1354(00)00036-1

[9] Swamee, P.K. \& Tyagi, A., Describing water quality with aggregate index. Journal of Environmental Engineering, 126, pp. 451-455, 2000. doi:10.1061/(ASCE)0733-9372 (2000)126:5(451)

[10] Bordalo, A.A., Nilsumranchi, W. \& Chalermwat, K., Water quality and uses of the Bangpakong River (Eastern Thailand). Water Research, 35, pp. 3535-3642, 2001. doi:10.1016/S0043-1354(01)00079-3

[11] Cude, C., Oregon water quality index: a tool for evaluating water quality management effectiveness. Journal of American Water Research Association, 37, pp. 125-137, 2001. doi:10.1111/ j.1752-1688.2001.tb05480.x

[12] Nagel, J.W., A water quality index for contact recreation. Water Science and Technology, 43, pp. 285-292, 2001.

[13] Jonnalagadda, S.B. \& Mhere, G., Water quality of the Odzi river in the eastern highlands of Zimbabwe. Water Research, 35, pp. 2371-2376, 2001. doi:10.1016/S0043-1354(00)00533-9

[14] Liou, S.M., Lo, S.L. \& Hu, C.Y., Application of two-stage fuzzy set theory to river quality evaluation in Taiwan. Water Research, 37, pp. 1406-1416, 2003. doi:10.1016/S0043-1354(02)00479-7

[15] Hernández-Romero, A.H., et al., Water quality and presence of pesticides in a tropical coastal wetland in southern Mexico. Marine Pollution Bulletin, 48, pp. 1130-1141, 2004. doi:10.1016/j. marpolbul.2004.01.003

[16] Stambuk-Giljanović, N., Comparison of Dalmatian water evaluation indices. Water Environment Research, 75(5), pp. 388-405, 2003. doi:10.2175/106143003X141196

[17] Brown, R.M., et al., A water quality index - do we dare? Water Sewage Works, 11, pp. 339-343, 1970.

[18] Khuzestan Water and Wastewater Company, Annual Quality Evaluation of Karoon River, Iranian Ministery of Energy: Ahvaz, Iran, 2008.

[19] APHA, Standard Methods for the Examination of Waters and Wastewaters, 21st edn, American Public Health Association (APHA): Washington, DC, 2005.

[20] Naddafi, K., Honari, H. \& Ahmadi, M., Water quality trend analysis for the Karoon River in Iran. Environmental Monitoring and Assessment, 134,pp.305-312,2007. doi:10.1007/s10661-007-9621-6

[21] OTT, W.R., Environmental Indices-Theory and Practice, Ann Arbor Science Publishers Inc.: Michigan, USA, 1980.

[22] Iranian Deputy of Environment, Environmental Guidelines and Standards, Iranian Deputy of Environment Publication: Tehran, Iran, 2005.

[23] Shamsaei, A., Qareei Zadeh, S. \& Sarang, A., The comparison of water indices and zoning quality in Karoon and Dez rivers. Water and Wastewater, 16(3), pp. 39-48, 2005. (In Persian). 